International Journal of Current Microbiology and Applied Sciences

ISSN: 2319-7706 Volume 10 Number 01 (2021)

Journal homepage: http://www.ijcmas.com

\title{
Influence of Post-harvest Chemical Treatments on Shelf life of Gerbera (Gerbera jamesonii)
}

\author{
C. Krishnamoorthy* \\ Department of Horticulture, Vanavarayar Institute of Agriculture, \\ Pollachi, Tamil Nadu, India \\ *Corresponding author
}

\section{A B S T R A C T}

\section{Keywords}

Post-harvest,

Chemical treatments, Shelf life, Gerbera

Article Info

Accepted:

12 December 2020

Available Online:

10 January 2021
A Lab experiment was conducted at Vanavarayar Institute of Agriculture, Pollachi, Tamil Nadu with an objective of studying the influence of chemicals for better vase life of Gerbera. The experiment was carried out during March - April 2016 in a completely randomized design (CRD). The experiment consisted of seven treatments with pink coloured variety. Six different types of chemicals are used in this study viz., Boric acid (2\%), Sucrose (3\%), Calcium Chloride (0.3\%), Salicylic acid (300ppm), Citric acid (300ppm), Ascorbic acid (2\%) with water as blank. The observations were recorded on various parameters like fresh weight $(\mathrm{g})$, flower diameter $(\mathrm{cm})$, solution uptake $(\mathrm{ml})$, flower longevity (days). The results indicated that the treatment $\mathrm{T}_{5}$ (Citric acid) has highest diameter of $26.83 \mathrm{~cm}$ while on treatment the same treatment recorded $9.50 \mathrm{~cm}$ diameter. The higher amount of water uptake of the flower was recorded in $\mathrm{T}_{5}$ (Citric acid) of $90 \mathrm{ml}$. The highest vase life of the flower was recorded in Calcium chloride $0.3 \%\left(\mathrm{~T}_{3}\right)$ followed by Sucrose 3\% $\left(\mathrm{T}_{2}\right)$.

\section{Introduction}

In the modern horticulture, there is more interest to find economic effective preservatives to improve post-harvest life of cut flowers, gerbera (Gerbera jamesonii) is one of the popular cut flowers in the world having short vase life and mostly are used freshly, so their vase life improvement is one of the first floriculture purposes (Cho et al., 2007). The major reasons for shorten vase life of cut flowers are nutrient deficiency, bacterial and fungal contaminations, water stress induced wilting and vascular blockage. 
Application of various chemicals could alter the post-harvest life of cut flowers (Sajjad Ahmadnia et al., 2013). Different chemicals have been used in vase solution to extend the vase life of cut flowers mainly by improving their water uptake and reducing transpiration, thereby promote the vase life (Mousa et al., 2009).

Aim of this study was to search for the preservative solutions for extending vase life of cut gerbera. Some of the chemicals are commercially used for extending the shelf life of flowers. Some of them are 8hydroxyquinoline sulphate, sucrose, silver nitrate, boric acid, calcium chloride, citric acid, sodium chloride and copper sulphate etc. Plants produce sugar through photosynthesis from water, carbon dioxide, and sunlight. When a flower is cut from the plant, photosynthesis is no longer an option for the production of sugar.

Chemicals provide a nutrient supplement to assure the continuation of development of the flower bud into a fully opened and beautiful flower. With the use of chemicals, the flower will perform better in terms of size, color, and vase life. Chemicals help lower the $\mathrm{pH}$ which keeps the water and food conducting system in flowers working at maximum efficiency. When a flower has been dehydrated through the normal course of postharvest and shipping it needs a jump-start. When the $\mathrm{pH}$ of a solution if more acidic, the molecules are more hydrophilic or they tend to stick together more. A good chemical includes an agent to lower the $\mathrm{pH}$ of the solution which encourages hydration, keeping the tiny tubes, or vessels, in the stem continually drawing up water (Lavanya et al., 2014).

From grower to end consumer in the transport chain, a flower is exposed to many chances of becoming exposed to debris which can clog the stems, resulting in the reduction of ability to take up water and nutrients. This blockage can easily shorten the life of a flower and result in a higher percentage of non-usable products by the retail florist, or even an unhappy customer. Chemicals includes a special ingredient to keep the water uptake flowing. With this background in consideration, the experiment was taken up to study the influence of post-harvest chemical treatments on shelf life of gerbera.

\section{Materials and Methods}

The study was conducted at Vanavarayar Institute of Agriculture, Pollachi, Tamil Nadu. Geographically it is located at $11^{0} 02 \mathrm{~N}$ latitude, $77^{\circ} 03 " \mathrm{E}$ longitude and at an altitude of $426.76 \mathrm{M}$ above MSL. The study was carried out during 2017 - 2018. Pink colour variety (Variety: Elegant Pink) of gerbera flowers were collected to carry out the study.

The research work was carried out under lab condition. The experiment was laid out in a Completely Randomized Design (CRD) with ten treatments replicated thrice. The size of conical flask used is $250 \mathrm{ml}$ Flask. The main factor is variety and the sub factors are $\mathrm{T}_{0-}$ Water (Blank), $\mathrm{T}_{1^{-}}$Boric acid (2\%), $\mathrm{T}_{2^{-}}$ Sucrose $(3 \%), \mathrm{T}_{3}-$ Calcium Chloride $(0.3 \%)$, $\mathrm{T}_{4}-$ Salicylic acid (300ppm), $\mathrm{T}_{5}-$ Citric acid (300ppm), $\mathrm{T}_{6-}$ Ascorbic acid (2\%).

The chemicals used in the study are as follows

Boric acid: $1 \mathrm{ml}$ of ethanol is added to $2 \mathrm{~g}$ boric acid powder to dissolve it, since it will not in dissolve in water, then $99 \mathrm{ml}$ of distilled water is added to make $2 \%$ boric acid.

Sucrose: $\quad 3 g$ of sucrose is dissolved in $100 \mathrm{ml}$ of distilled water to make $3 \%$ of sucrose solution. 
Calcium chloride: $0.3 \mathrm{~g}$ of $\mathrm{CaCl}_{2}$ is added to $100 \mathrm{ml}$ of distilled water to make $0.3 \%$ of $\mathrm{CaCl}_{2}$ solution.

Salicylic acid: $0.3 \mathrm{mg}$ Salicylic acid is dissolved first with $1 \mathrm{ml}$ of ethanol and then the volume is made upto $100 \mathrm{ml}$ by adding $99 \mathrm{ml}$ of distilled water to make $300 \mathrm{ppm}$ of salicylic acid.

Citric acid: Citric acid of $0.3 \mathrm{~g}$ is dissolved in ethanol of $1 \mathrm{ml}$ and $99 \mathrm{ml}$ of distilled water is added to make $300 \mathrm{ppm}$ of citric acid.

Ascorbic acid: $1 \mathrm{ml}$ of ethanol is added to $2 \mathrm{~g}$ Ascorbic acid powder to dissolve it, since it will not in dissolve in water, then $99 \mathrm{ml}$ of distilled water is added to make $2 \%$ Ascorbic acid.

\section{Observation}

One flower in each treatment in each replication were selected at random and utilized for recording observations on the following characters and the mean values were subjected to statistical analysis. The observations were taken at $1^{\text {st }}, 2^{\text {nd }}, 3^{\text {rd }}, 6^{\text {th }}, 7^{\text {th }}$, $8^{\text {th }}$ days. Fully opened flowers were used for recording observations.

\section{Fresh weight}

Fresh weight of the flowers was determined just before the immersion of the flowers into the solutions and repeated until the vase life of the flowers was terminated. The fresh weight of each flower was expressed in grams (Hailay Gebremedhin et al., 2013).

\section{Flower diameter}

The initial diameter of each flowers are recorded before placing it in a holding solution. The flower diameter was recorded until the flowers showed symptoms of bent neck (Kamran Asadi et al., 2014).
The flower diameter is measured using the ruler.

\section{Solution uptake}

Solution uptake was determined by taking flower stalks and subtracting the volume of water evaporated from a flask of the same volume without cut flower using volumetric flasks (Mahfam Hamidi Imani et al., 2013).

\section{Flower longevity (Vase life)}

After storage, the flowers were taken out from the pack. The stem ends were recut diagonally and their vase life was noted by daily evaluation of the appearance of the flowers. The flowers were placed individually in holding prepared solutions and distilled water in conical flasks. Each flower was tagged. Flower longevity was recorded as the number of days on vase until the flowers showed symptoms of bent neck or advanced signs of fading on all petals (Hailay Gebremedhin et al., 2013).

\section{Statistical analysis}

The experimental data were statistically analyzed as per the method suggested by Panse and Sukhatme (1978). The critical difference was worked out for 5 percent (0.05) probability.

\section{Results and Discussion}

Wide ranges of variations among the treatments were observed for the traits.

\section{Diameter of flower}

The diameter of the flowers gradually increases with flower opening and it surprises to reduce due to senescence. On $\mathrm{T}_{5}$ has highest diameter of $26.83 \mathrm{~cm}$ while on treatment the same treatment recorded 9.50 cm diameter (Table 1). 


\section{Solution uptake of flower}

The higher amount of water uptake of the flower was recorded in $\mathrm{T}_{5}$ (Citric acid) of 90ml. $\mathrm{T}_{2}$ (sucrose) and $\mathrm{T}_{3}$ (Calcium chloride) were similar with each other with solution uptake of $60 \mathrm{ml}$.Control has the lowest solution uptake of $40 \mathrm{ml}$ respectively (Table 2).

\section{Vase life of the flower}

The highest vase life of the flower was recorded in $\mathrm{T}_{3}$ Calcium chloride $0.3 \%$ followed by $\mathrm{T}_{2}$ Sucrose $3 \%$. While $\mathrm{T}_{1}$ Boric acid $2 \%$ has the lowest vase life (Table 3 ).

\section{Petal colour}

All treatment on the first day remains green, while $T_{3}$ and $T_{6}$ slightly changes to brown colour and on the last day all petal colour changes to brown colour (Table 4).

\section{Stem texture}

Stem texture remains hard for the first day, $\mathrm{T}_{1}$ and $\mathrm{T}_{6}$ turns semi-hard hard on the second day. While $\mathrm{T}_{2}$ and $\mathrm{T}_{3}$ remains semi-hard until the $6^{\text {th }}$ day and at the last day all flower stem turns to soft (Table 5).

Table.1 Influence of post-harvest chemical treatments on diameter of the flowers $(\mathrm{cm})$

\begin{tabular}{|c|c|c|}
\hline Treatment & $\begin{array}{c}\text { Diameter of the flowers } \\
\text { before treatment } \mathbf{( c m )}\end{array}$ & $\begin{array}{c}\text { Diameter of flowers after } \\
\text { treatment } \mathbf{( c m})\end{array}$ \\
\hline $\mathbf{T}_{\mathbf{0}}$ & 27.00 & 6.75 \\
\hline $\mathbf{T}_{\mathbf{1}}$ & 21.83 & 8.16 \\
\hline $\mathbf{T}_{\mathbf{2}}$ & 23.83 & 9.00 \\
\hline $\mathbf{T}_{\mathbf{3}}$ & 26.50 & 8.16 \\
\hline $\mathbf{T}_{\mathbf{4}}$ & 26.16 & 7.83 \\
\hline $\mathbf{T}_{\mathbf{5}}$ & 26.83 & 9.50 \\
\hline $\mathbf{T}_{\mathbf{6}}$ & 26.33 & 8.16 \\
\hline Grand Mean & 25.35 & 8.16 \\
\hline $\mathbf{S D}$ & 1.85 & 9.00 \\
\hline $\mathbf{C V}(\mathbf{\%})$ & 7.30 & 8.16 \\
\hline
\end{tabular}

Table.2 Influence of post-harvest chemical treatments on solution uptake of flowers

\begin{tabular}{|c|c|}
\hline Treatment & Solution uptake of flowers $(\mathbf{m l})$ \\
\hline $\mathbf{T}_{\mathbf{0}}$ & 40 \\
\hline $\mathbf{T}_{\mathbf{1}}$ & 70 \\
\hline $\mathbf{T}_{\mathbf{2}}$ & 60 \\
\hline $\mathbf{T}_{\mathbf{3}}$ & 60 \\
\hline $\mathbf{T}_{\mathbf{4}}$ & 65 \\
\hline $\mathbf{T}_{\mathbf{5}}$ & 90 \\
\hline $\mathbf{T}_{\mathbf{6}}$ & 80 \\
\hline
\end{tabular}


Table.3 Influence of post-harvest chemical treatments on vase of life cut gerbera

\begin{tabular}{|c|c|c|c|}
\hline \multirow{2}{*}{ Treatment } & \multicolumn{3}{|c|}{ Vase of life cut gerbera (days) } \\
\cline { 2 - 4 } & $\mathbf{F}_{\mathbf{1}}$ & $\mathbf{F}_{\mathbf{2}}$ & $\mathbf{F}_{\mathbf{3}}$ \\
\hline $\mathbf{T}_{\mathbf{0}}$ & 4 & 4 & 4 \\
\hline $\mathbf{T}_{\mathbf{1}}$ & 2 & 2 & 2 \\
\hline $\mathbf{T}_{\mathbf{2}}$ & 5 & 5 & 5 \\
\hline $\mathbf{T}_{\mathbf{3}}$ & 6 & 6 & 6 \\
\hline $\mathbf{T}_{\mathbf{4}}$ & 2 & 2 & 2 \\
\hline $\mathbf{T}_{\mathbf{5}}$ & 5 & 5 & 5 \\
\hline $\mathbf{T}_{\mathbf{6}}$ & 2 & 2 & 2 \\
\hline
\end{tabular}

Table.4 Influence of post-harvest chemical treatments on petal colour

\begin{tabular}{|l|l|l|l|l|l|l|l|}
\hline Treatments & \multicolumn{7}{|c|}{ Days } \\
\cline { 2 - 8 } & $\mathbf{1}$ & \multicolumn{2}{|c|}{$\mathbf{2}$} & \multicolumn{1}{|c|}{$\mathbf{4}$} & \multicolumn{1}{c|}{$\mathbf{5}$} & \multicolumn{1}{c|}{} \\
\hline $\mathbf{T}_{\mathbf{0}}$ & Pink & Pink & Partially Brown & Brown & Brown & Brown & Brown \\
\hline $\mathbf{T}_{\mathbf{1}}$ & Pink & Pink & Partially brown & Brown & Brown & Brown & Brown \\
\hline $\mathbf{T}_{\mathbf{2}}$ & Pink & Pink & Pink & Pink & Pink & Pink & Pale pink \\
\hline $\mathbf{T}_{\mathbf{3}}$ & Pink & Pink & Pink & Pink & Pink & Pink & Pale pink \\
\hline $\mathbf{T}_{\mathbf{4}}$ & Pink & Pink & Pink & $\begin{array}{l}\text { Partially } \\
\text { Brown }\end{array}$ & Brown & Brown & Brown \\
\hline $\mathbf{T}_{\mathbf{5}}$ & Pink & Pink & Partially Brown & Brown & Brown & Brown & Brown \\
\hline $\mathbf{T}_{\mathbf{6}}$ & Pink & $\begin{array}{l}\text { Partially } \\
\text { brown }\end{array}$ & Partially Brown & Brown & Brown & Brown & Brown \\
\hline
\end{tabular}

Table.5 Influence of post-harvest chemical treatments on stem texture

\begin{tabular}{|c|c|c|c|c|c|c|c|}
\hline \multirow[t]{2}{*}{ Treatments } & \multicolumn{7}{|c|}{ Days } \\
\hline & 1 & 2 & 3 & 4 & 5 & 6 & 7 \\
\hline $\mathbf{T}_{\mathbf{0}}$ & Hard & Hard & $\begin{array}{l}\text { Semi- } \\
\text { hard }\end{array}$ & $\begin{array}{l}\text { Semi- } \\
\text { hard }\end{array}$ & Soft & Soft & Soft \\
\hline $\mathbf{T}_{1}$ & Hard & $\begin{array}{l}\text { Semi- } \\
\text { Hard }\end{array}$ & $\begin{array}{l}\text { Semi- } \\
\text { hard }\end{array}$ & $\begin{array}{l}\text { Semi- } \\
\text { hard }\end{array}$ & Soft & Soft & Soft \\
\hline $\mathbf{T}_{2}$ & Hard & Hard & $\begin{array}{l}\text { Semi- } \\
\text { hard }\end{array}$ & $\begin{array}{l}\text { Semi- } \\
\text { hard }\end{array}$ & $\begin{array}{l}\text { Semi- } \\
\text { hard }\end{array}$ & $\begin{array}{l}\text { Semi- } \\
\text { hard }\end{array}$ & Soft \\
\hline $\mathbf{T}_{2}$ & Hard & Hard & $\begin{array}{l}\text { Semi- } \\
\text { hard }\end{array}$ & $\begin{array}{l}\text { Semi- } \\
\text { hard }\end{array}$ & $\begin{array}{l}\text { Semi- } \\
\text { hard }\end{array}$ & $\begin{array}{l}\text { Semi- } \\
\text { hard }\end{array}$ & Soft \\
\hline $\mathbf{T}_{4}$ & Hard & Hard & $\begin{array}{l}\text { Semi- } \\
\text { hard }\end{array}$ & $\begin{array}{l}\text { Semi- } \\
\text { hard }\end{array}$ & Soft & Soft & Soft \\
\hline $\mathbf{T}_{5}$ & Hard & Hard & $\begin{array}{l}\text { Semi- } \\
\text { hard }\end{array}$ & $\begin{array}{l}\text { Semi- } \\
\text { hard }\end{array}$ & Soft & Soft & Soft \\
\hline $\mathbf{T}_{6}$ & Hard & $\begin{array}{l}\text { Semi- } \\
\text { Hard }\end{array}$ & $\begin{array}{l}\text { Semi- } \\
\text { hard }\end{array}$ & $\begin{array}{l}\text { Semi- } \\
\text { hard }\end{array}$ & Soft & Soft & Soft \\
\hline
\end{tabular}


The results obtained from the trails were subjected to statistical analysis and the conclusions drawn are discussed. All the chemical treatments were found to be superior over the control treatment.

\section{Weight of flower}

In gerbera the weight of the flowers increases up towards flower opening and its weight gradually decline with the senescence of the flowers in almost all treatments. Among these 20 flowers every flower has an equal weight of exactly $15 \mathrm{~g}$. Sugar effect on further increasing the osmotic pressure increases is relative to water content in stems and flowers and thus improves the ability to absorb water (Kamran Asadi et al., 2014). The similar results with increase in fresh weight before senescence were also reported by $\mathrm{Pal}$ et al., 2003.

\section{Diameter of flower}

The diameter of the flowers gradually increases with flower opening and it surprises to reduce due to senescence. On $5^{\text {th }}$ treatment $\mathrm{F}_{2}$ has highest diameter of $30 \mathrm{~cm}$ while on $\mathrm{T}_{0^{-}}$ $\mathrm{F}_{2}$ recorded $28.5 \mathrm{~cm}$ diameter which follows $\mathrm{F}_{2}$. On flower bud expansion that carbohydrates are necessary for turgor pressure maintenance and important energy sources facilitating flower opening which shows similarity with results from Hailay Gebremedhin et al., (2013). Senescing carnation flowers exhibit a climacteric-like rise in ethylene production and exposure of carnation flowers to exogenous ethylene induces in rolling of petals, triggering ethylene synthesis, and inducing chemical and physical changes in microsomal membrane lipids of senescing petals (Jamie, 2003).

\section{Solution uptake of flower}

Water uptake $\mathrm{T}_{5}$ of has significantly high water uptake when comparing with the other treatments and other variety shows, Nijsse et al., (2001) realized that variability among cultivars as to water uptake may be due to differences in xylem anatomy, which has been shown to greatly influence hydraulic conductivity. Usually, solution uptake decreased with increasing storage time. This could be due to air embolism of cut stem, proliferation of microbes, and plant reaction to wounding as described by Hailay Gebremedhin et al., (2013).

\section{Vase life of the flower}

In gerbera the vase life of the flower shows variable results that $T_{3}$ has longest vase life of six days. Petal senescence was seen on $\mathrm{T}_{1}, \mathrm{~T}_{4}$, $\mathrm{T}_{6}$ on the second day and on the next day all the treatment flowers has start their petal discoloration. However, petal senescence in Famosa was accompanied by reduced total ACC and ethylene production (Asghar Ebrahimzadeh et al., 2013).

\section{References}

Asghar Ebrahimzadeh, Silvia JiménezBecker, Libia Acened Chaparro-Torres, Juan Pablo Fernandez-Trujillo and Maria Serrano-Mula. 2013. Postharvest petal senescence of two cultivars of carnation flowers with different vase lives. Australian Journal of crop Science, 7(12): 1829-1835.

Cho, M. C., F. G. Celikel, L. Dodge and Reid, M. S. 2007. Sucrose enhances the postharvest quality of cut flowers of Eustoma grandiflorum (Raf.) Shinn. Acta Horticulture. 543: 305-315.

Hailay Gebremedhin, Bizuayehu Tesfaye, Ali Mohammed and Dargie Tsegay. 2013. Influence of preservative solutions on vase life and postharvest characteristics of rose (Rosa hybrida) cut flowers. International Journal for Biotechnology and Molecular Biology Research. 4(8): 111-118. 
Jamie, A., 2003. The cut flower: Post harvest considerations. Journal of Biological Sciences. 3(4): 406-442.

Kamran Asadi, Vahid Abdoosi, Elham Sadat Mousavi and Aida Abdali. 2014. Evaluation the effect of sucrose and $\mathrm{GA}_{3}$ treatment on vase life carnation cut flower (Dianthus caryophyllus var Yellow). Advances in Applied Science Research. 5(6): 150-154.

Lavanya, V., K. Udaykumar Nidoni, H. Sharanagouda, C. T. Ramachandra, A. R. Kurubar and Ramya, V. 2014. Petal Senescence in Jasmine Flowers (Jasminum sambac) during storage by using Different Packaging Materials and Pre-Treatment: Role of Phenolics. International Journal of Science and Environment. 3(6): 2130-2135.

Mahfam Hamidi Imani, Davood Hashemabadi, Behzad Kaviani and Mohammad Zarchini. 2013. Improving Water Relations and Postharvest Quality of Cut Rose by Ethanol. Annals of Biological Research. 4(1): 256-259.

Mousa, S., K. Mosen, S. T. Toktam and Roohangiz, N. 2009. Essential oils and silver nanopartirles (SNP) as novel agents to extend vase- life of gerbera (Gerbera jomesonii cv. Dune) flowers. Post-harvest Biology. 53(3): 155-158.

Nijsse, J., G. Van der Heijden, W. Van Ieperen, C. Keijzer and Van Meeteren, V. 2001. Xylem hydraulic conductivity related to conduit dimensions along chrysanthemum stems. Journal of Experimental Botany. 52: 319-327.

Pal, A., S. Kumar and Srivastava, R. 2003. Effect of floral preservatives on postharvest management in gladiolus spikes. Journal of Ornamental Horticulture. 6(4): 367-371.

Panse, V.G., and Sukhatme, P.V. 1978. Statistical method for agricultural workers, II Edition ICAR, New Delhi, India.

Sajjad Ahmadnia, Davood Hashemabadi and Shahram Sedaghathoor. 2013. Effects of Boric Acid on Postharvest Characteristics of Cut Carnation (Dianthus caryophyllus L. cv. Nelson). Annals of Biological Research. 4 (1): 242-245.

\section{How to cite this article:}

Krishnamoorthy, C. 2021. Influence of Post-harvest Chemical Treatments on Shelf life of Gerbera (Gerbera jamesonii). Int.J.Curr.Microbiol.App.Sci. 10(01): 1716-1722. doi: https://doi.org/10.20546/ijcmas.2021.1001.201 